\title{
The Coordination Chemistry of Bio-Relevant Ligands and Their Magnesium Complexes
}

\author{
Derek R. Case, Jon Zubieta * and Robert P. Doyle *(i) \\ Department of Chemistry, Syracuse University, 111 College Place, Syracuse, NY 13244, USA; drcase@syr.edu \\ * Correspondence: jazubiet@syr.edu (J.Z.); rpdoyle@syr.edu (R.P.D.)
}

Academic Editor: George E. Kostakis

Received: 22 June 2020; Accepted: 8 July 2020; Published: 11 July 2020

\begin{abstract}
The coordination chemistry of magnesium $\left(\mathrm{Mg}^{2+}\right)$ was extensively explored. More recently; magnesium; which plays a role in over $80 \%$ of metabolic functions and governs over 350 enzymatic processes; is becoming increasingly linked to chronic disease-predominantly due to magnesium deficiency (hypomagnesemia). Supplemental dietary magnesium utilizing biorelevant chelate ligands is a proven method for counteracting hypomagnesemia. However, the coordination chemistry of such bio-relevant magnesium complexes is yet to be extensively explored or elucidated. It is the aim of this review to comprehensively describe what is currently known about common bio-relevant magnesium complexes from the perspective of coordination chemistry.
\end{abstract}

Keywords: magnesium; chelates; coordination chemistry; hypomagnesemia; nutraceuticals

\section{Introduction}

Magnesium is the fourth most common element in the human body and is the second most common intracellular cation after potassium [1]. Magnesium is involved as a cofactor for more than 300 enzymes and 800 proteins [1-3] and it is required for energy production, oxidative phosphorylation, and glycolysis, amongst others. Magnesium contributes to the structural development of bone, with external layers of which aid in maintaining blood levels of magnesium [4] and magnesium deficiency linked to reduced bone mass [5,6]. Magnesium is required for the synthesis of DNA [7,8], RNA [9,10] and the antioxidant glutathione [11]. Magnesium also plays a role in the active transport of calcium and potassium ions across cell membranes, a process critical for nerve impulse conduction and muscle contraction including normal heart rhythm [12-14].

Several studies now support that an estimated $50-60 \%$ of Americans do not consume enough magnesium in their diets [15-21]. The concept of chronic latent magnesium depletion (hypomagnesaemia), defined as $<0.75 \mathrm{mmol} / \mathrm{L}$ in blood [22] is not new, yet deficiency of magnesium remains an often unrecognized and widespread reality in the modern world [23]. Furthermore, insufficient magnesium is linked to a spectrum of clinical afflictions, including arrhythmias [24], hypertension [25,26], coronary artery disease [27-29], migraines/headaches [30], osteoporosis [31-33] and type 2 diabetes mellitus (T2DM) [28,34,35].

Given the prevalence of magnesium deficiency and hypomagnesaemia and its association with chronic disease states, there was a significant increase in interest in magnesium supplementation as a viable means of treatment $[26,32,35,36]$. This review focuses on the chemistry of bio-relevant magnesium complexes as it relates to complex geometry and degree of coordination, ligand coordination modes, behavior at varying $\mathrm{pH}$ values, inner- and outer-sphere coordination, and charge. 


\section{Discussion}

\subsection{Chemical/Physical Characteristics and Applications of Magnesium $\left(\mathrm{Mg}^{2+}\right)$}

Magnesium was recognized as an element as early as 1755 and was isolated in 1808 [37]. Magnesium is a grayish metal [38], atomic number 12 [37], with an atomic weight of 24.3 Da [37].

Organomagnesium salts such as magnesium halides (of the type $\mathrm{MgX} ; \mathrm{X}=\mathrm{Cl}, \mathrm{Br}$, etc.) are used extensively in Grignard-type organic syntheses [37,39]. Other organomagnesium complexes are biorelevant, such as magnesium citrate, and they are subject to constraints of the solution state. Magnesium has a high affinity for hydration water; more specifically, magnesium's hydrated radius is approximately 400 times larger than that of its dehydrated radius [2]. In fact, it was previously established that, in aqueous conditions, not dissimilar to physiological conditions, magnesium will readily form hexaaquomagnesium ions $\left(\left[\mathrm{Mg}\left(\mathrm{H}_{2} \mathrm{O}\right)_{6}\right]^{2+}\right)[40]$.

\subsection{Biological Relevance of Magnesium}

Evidence to support the biological relevance of magnesium is inscrutable. The importance of magnesium is placed heavily on the distribution of magnesium throughout the body and the processes through which it is utilized, such as the maintenance of bone mass and the synthesis of adenosine triphosphate (ATP). Subsequently, an understanding of magnesium distribution throughout the body is integral to understanding its biological relevance and implication as a coordinate cation [1,2,4].

\subsubsection{Storage and Occurrence}

The average adult body contains $25 \mathrm{~g}$ of magnesium [41]. Magnesium is stored unequally throughout the body; approximately $99 \%$ of bodily magnesium is intracellular with $90 \%$ stored in bone and muscle tissue, and the remaining $<1 \%$ is distributed in the blood [2,42-44]. Of the magnesium stored in bone and other assorted soft tissue, approximately 50-60\% is stored solely within bone [1]. There is a delicate homeostasis maintained between bone concentrations and blood concentrations of magnesium, which results in the replenishing of blood magnesium from the outer layers of bone [4]. Magnesium within muscle and soft tissue accounts for $27 \%$ and $19 \%$ of total bodily magnesium, respectively [42]. The remaining $1 \%$ of bodily magnesium is distributed within the blood and is extracellular magnesium [2]. Extracellular magnesium exists as either free/ionized (55\%), bound to proteins such as albumin or globulin (30\%), or complexed with biological anions (15\%) such as ATP (as illustrated in Figure 1) [1,2,45].<smiles>O=P([O-])([O-])OP(=O)([O-])O[Ge]</smiles>

Figure 1. Structural illustration of the extracellular magnesium-ATP complex found in blood $[1,3]$.

\subsubsection{Magnesium Uptake in the Gastrointestinal (GI) Tract}

Uptake of magnesium thought the gastrointestinal tract (GI) varies, with the bulk of magnesium absorption occurring in the ileum (Table 1) [46]. 
Table 1. Contribution of specific portions of the gastrointestinal tract (GI) on magnesium uptake.

\begin{tabular}{cccc}
\hline GI Tract Segment & $\mathbf{p H}$ & $\begin{array}{c}\text { Contribution of } \\
\text { Magnesium Uptake (\%) }\end{array}$ & Reference \\
\hline Duodenum & $5.9-6.8$ & 11 & {$[46-60]$} \\
Colon & $5.7-7.2$ & 11 & {$[46-60]$} \\
Jejunum & $5.9-6.8$ & 22 & {$[46-60]$} \\
Ileum & $7.3-7.6$ & 56 & {$[46-60]$} \\
\hline
\end{tabular}

Absorption throughout the GI is largely pH-dependent (Table 1), as illustrated by Thongon et al. [46,61], with the $\mathrm{pH}$ of the entire human small bowel ranging from 5.5-7 [47]. Increased magnesium absorption in the ileum is due to a more acidic luminal $\mathrm{pH}$ [48]. The unequal absorption of magnesium along the GI is also impacted by uptake pathway. The two available pathways that contribute to uptake are the non-saturable passive paracellular pathway (PPP), which is responsible for $80-90 \%$ of magnesium absorption along the length of the GI, and the saturable, active transcellular pathway (TP) $[2,40,44]$.

The PPP is responsible for larger magnesium loads ( $\geq 250 \mathrm{mg}$ ) and is driven by an electrochemical gradient and solvent drag of $\mathrm{Mg}^{2+}$ between intestinal enterocytes. Successful propagation of $\mathrm{Mg}^{2+}$ between enterocytes is facilitated by tight-junction proteins known as claudins, which are responsible for stripping $\mathrm{Mg}^{2+}$ of its extensive hydration sphere [1,2]. The TP is responsible for the uptake of smaller magnesium loads $(<125-250 \mathrm{mg})$; this is a result of the saturation of transient receptor potential channel melatstatin (TRPM 6 and TRPM 7), which facilitates removal of the magnesium hydration sphere, much like the claudins of the PPP $[1,2,62,63]$. At $\mathrm{Mg}^{2+}$ loads greater than those manageable by the TP, the bulk of uptake is mediated by the PPP $[62,63]$.

\subsection{Evaluating Magnesium Deficiency and Impact of Complex Composition on Uptake}

Addressing magnesium deficiency status is complicated by several contributory factors. Firstly, $99 \%$ of total body $\mathrm{Mg}^{2+}$ is intracellular, with approximately $90 \%$ compartmentalized in bone and muscle, and the remainder $(<1 \%)$ being distributed in blood [44]. This distribution of $\mathrm{Mg}^{2+}$ results in blood magnesium concentration being an inaccurate determinant of total body magnesium [5,27]. In addition, there are multiple complex factors that play a role in the absorption of magnesium such as utilization of both the TP and the PPP [1,2] and the impacts of intestinal luminal $\mathrm{pH}$ relative to magnesium absorption in the gut $[22,64]$. These factors make the claim of a certain percentage of gastrointestinal magnesium uptake, as based upon common analysis methods (Table 2), misleading [2]. Consequently, magnesium is one of the most poorly understood and appreciated minerals in human nutrition.

Table 2. Common methods used for the determination of magnesium status with pros and cons.

\begin{tabular}{ccc}
\hline Analysis Method & Advantages & Difficulties \\
\hline Serum & $\begin{array}{c}\text { Rapid and easy } \\
\text { Urine Excretion }\end{array}$ & $\begin{array}{c}\text { Valuable for tracking kidney wasting } \\
\left(\text { high }\left[\mathrm{Mg}^{2+}\right] \text { ) or intake issues (low }\right. \\
\left.\left[\mathrm{Mg}^{2+}\right]\right)\end{array}$ \\
$\begin{array}{c}\text { Confirmed role of small intestine in } \\
\text { absorption }\end{array}$ & Time consuming \\
Isotopic Analysis & Confined to laboratory research \\
\hline
\end{tabular}

Nevertheless, understanding magnesium deficiency is integral to developing adequate treatment methods. Thus far, and most ubiquitously, magnesium supplements (including magnesium oxide, magnesium hydroxide, magnesium chloride, magnesium sulfate, magnesium lysinate, magnesium malate, magnesium glycinate, and magnesium aspartate) are used as a viable treatment for magnesium deficiency $[26,32,35,36,65-67]$. However, the physical properties of various $\mathrm{Mg}^{2+}$ forms will affect the behavior of any complex in the GI tract and beyond and will influence a key metric of any compound for oral ingestion, i.e., bioavailability. 


\subsection{Magnesium Bioavailability}

There are many physical factors that were shown to impact magnesium bioavailability, such as dose load/frequency [68-70] and age [71]. There are also many chemical factors, most significantly solubility $[67,72-74]$. The bioavailability of $\mathrm{Mg}^{2+}$ within the GI exhibits correlative behavior relative to the water solubility of the complex. This indicates that complexes that exhibit greater solubility (see Table 3) within the physiological pH range of the GI tract are assumed to be more bioavailable.

Table 3. Common magnesium supplements and their solubilities. Table includes $p K a$ values for the terminal carboxylic proton $\left(\mathrm{pKa}_{1}\right)$ and the amino proton $\left(\mathrm{pKa}_{2}\right)$. Backbone protons are displayed as $\mathrm{pKa}_{3}$. The asterisk $\left({ }^{*}\right)$ represents the $\mathrm{pKa}$ of the first and second protons to be lost from the diacid sulfuric acid and the subsequent anion bisulfate, and the double asterisk $\left.{ }^{* *}\right)$ represents the pKa of the proton farthest from the backbone alcohol of the dicarboxylic acid malic acid.

\begin{tabular}{|c|c|c|c|c|}
\hline $\begin{array}{c}\text { Form } \\
\text { (Oxide/Salt/Chelate) }\end{array}$ & Acid/Base Chemistry & $\begin{array}{c}\text { Solubility } \\
\left(\mathrm{g} / 100 \mathrm{~mL} \mathrm{H}_{2} \mathrm{O}\right)\end{array}$ & MW g/mol (\%Mg) & Reference \\
\hline Magnesium oxide & Alkaline & 0.010 & $40.30(60.3)$ & [75] \\
\hline Magnesium citrate & Acidic $\left(\mathrm{pKa}_{1}=3.13\right)$ & 20 & $214.41(11.3)$ & [37] \\
\hline Magnesium chloride & Neutral & 56.0 & $95.21(25.5)$ & [76] \\
\hline Magnesium sulfate & $\begin{array}{c}\text { Acidic } \\
\left(\mathrm{pKa}_{1}=3.0 ; \mathrm{pKa}_{2}=1.99 *\right)\end{array}$ & 35.7 & $120.37(20.1)$ & [75] \\
\hline Magnesium orotate & Acidic $\left(\mathrm{pKa}_{1}=2.83\right)$ & Slightly soluble & $334.48(7.2)$ & [66] \\
\hline Magnesium taurate & $\begin{array}{c}\text { Acidic }\left(\mathrm{pKa}_{1}=1.50\right) \\
\text { Acidic }\end{array}$ & Slightly soluble & $272.57(8.9)$ & {$[77]$} \\
\hline Magnesium aspartate & $\begin{array}{c}\left(\mathrm{pKa}_{1}=1.88 ; \mathrm{pKa}_{2}=9.60\right. \\
\left.\mathrm{pKa}_{3}=3.65\right)\end{array}$ & 4.0 & $288.49(8.5)$ & [78] \\
\hline Magnesium threonate & Acidic $\left(\mathrm{pKa}_{1}=3.4\right)$ & Soluble & $294.50(8.3)$ & [79] \\
\hline Magnesium malate & $\begin{array}{c}\text { Acidic } \\
\left(\mathrm{pKa}_{1}=3.46 ; \mathrm{pKa}_{2}=5.10^{* *}\right)\end{array}$ & Slightly soluble & $156.37(15.5)$ & {$[80,81]$} \\
\hline Magnesium hydroxide & Alkaline & 0.00069 & $58.32(41.7)$ & [75] \\
\hline Magnesium carbonate & Weakly alkaline & 0.18 & $84.31(28.8)$ & [37] \\
\hline
\end{tabular}

Organic magnesium complexes show greater appreciable solubility than the commonly used magnesium oxide supplement, and the amino acids of these ligands occupy active sites on magnesium, reducing complexation with phytates and other inhibitory substances that reduce mineral absorption [1,2,46,62]. Occupation of these sites may reduce hydration of the magnesium, which could reduce the frequently encountered problem of laxation, a common feature with simple magnesium salts [1,2,46,62]. As such, organic- and amino-acid-based ligands as magnesium chelates provide an appropriate scaffold upon which to build and expand. However, given the factors that impact overall magnesium absorption from an administered complex, the design of an effective $\mathrm{Mg}^{2+}$ nutraceutical or pharmaceutical requires an appreciation of the chelation chemistry of magnesium and the subsequent coordinate ligand.

\subsection{Biorelevant Organic and Amino Acid Magnesium Complexes and Their Coordination}

We focus primarily herein on biorelevant magnesium complexes of organic and amino acid ligands. Although evaluation of these interactions shows that ligand coordination can be both inner-sphere (magnesium glycinate) [82,83] and outer-sphere (magnesium orotate, utilizing a hexaquomagnesium core) [84], given magnesium's high degree of hydration [2] (Figure 2), and interactions can be mono-, bi-, tri-, or tetradentate, little was done to determine the specific coordinative characteristics of specific magnesium-peptide complexes. 
<smiles>O[14C](O)(O)[14C](O)(O)O</smiles>

Inner Sphere<smiles>[Y]CP(O)[Y10]([O])(O)(O)O</smiles>

Outer Sphere<smiles>[Y]CP(O)[14C](O)(O)[14C](O)(O)O</smiles>
$\mathrm{X}=\mathrm{N}, \mathrm{O}$, etc.

Figure 2. Illustration of the different ligand coordination modes utilized by magnesium. Adapted from Weston [40].

Organic and amino acid ligands that were previously evaluated regarding magnesium coordination are shown in Table 4. All pKa values were taken from the Chemical Rubber Company's Handbook of Chemistry and Physics Table of Dissociation Constants of Organic Acids and Bases [85].

Table 4. Previously establishedand commonly used organic and amino acid chelate ligands for magnesium complexes. Table includes $\mathrm{pKa}$ values for the terminal carboxylic proton $\left(\mathrm{pKa}_{1}\right)$ and the amino proton $\left(\mathrm{pKa}_{2}\right)$. Backbone protons are displayed as $\mathrm{pKa}_{3}$. The asterisk $\left(^{*}\right)$ represents the secondary pKa of citric acid and malic acid, which have no amino proton-in the case of malic acid, the value is for the terminal carboxylic acid farthest from the backbone alcohol. The hyphen (-) indicates that the specified value does not apply to this specific ligand.

\begin{tabular}{lllll} 
Ligand & $\mathrm{pKa}_{1}$ & $\mathrm{pKa}_{2}$ & $\mathrm{pKa}_{3}$ & Lewis Bases \\
\hline & & & - & \\
\hline
\end{tabular}


Table 4. Cont.

\begin{tabular}{llllc}
\hline Ligand & $\mathrm{pKa}_{1}$ & $\mathrm{pKa}_{2}$ & $\mathrm{pKa}_{3}$ & Lewis Bases \\
\hline Malic Acid & 3.40 & $5.11^{*}$ & - & 3 \\
\hline
\end{tabular}

Understanding the pKa values of the terminal carboxylic acids, terminal amines, and available Lewis bases of the backbone of organic and amino acid chelates is integral to understanding the coordination chemistry of magnesium chelates. Changes in the $\mathrm{pH}$ of synthetic conditions can and will alter the outcome of the complex, as was the case with magnesium aspartate [65]. Whether or not an available Lewis base is protonated or deprotonated will dictate how a ligand coordinates, and, particularly in the case of amino acids with multiple Lewis bases, this may give rise to more entropically favored multidentate coordination modes.

\subsubsection{Orotic, Mandelic, and Anthranilic Acid}

Orotic acid (6-uracilic acid, 1,2,3,6-tetrahydro-2,6-diox0-4-pyrimidinecarboxylic acid—Figure 3) [86,87] is a pyrimidine that is relevant to biological systems as a precursor molecule to pyrimidine nucleosides (e.g., uridine and cytidine) [88]. Given the established biological relevance of orotic acid, it presented itself as a viable option to generate a magnesium chelate that could be utilized to combat magnesium deficiency. Findings reported by Schmidbaur et al. showed that magnesium orotate and the analogous lithium complex could be synthesized in high yield via a simple neutralization of the appropriate hydroxide salt with two equivalents of orotic acid, with the product obtained as a colorless crystalline material [84]. Single crystal X-ray diffraction studies showed a magnesium bis-orotate octahydrate complex within the monoclinic space group $\mathrm{P} 2{ }_{1} / \mathrm{C}$ (Figure 4) [84].<smiles>O=C(O)c1cc(=O)[nH]c(=O)[nH]1</smiles>

Figure 3. Structure of orotic acid. 


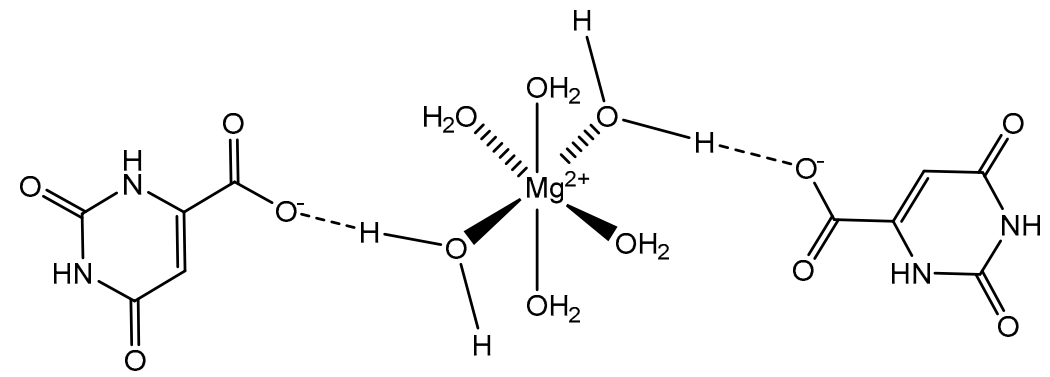

Figure 4. An illustration of the magnesium bis-orotate octahydrate reported by Schmidbaur et al. [84]. The pictorial representation is devoid of the two additional outer-sphere waters reported.

As illustrated, the complexed orotic acid does not coordinate to magnesium as a traditional chelate. In fact, the orotic acid forms a complex with magnesium via outer-sphere coordination as a result of an extensive hydrogen bonding network-most notably, the interaction between the deprotonated terminal carboxylic acid and the ubiquitous hexaaquo magnesium core described by Weston [40]. Schmidbaur goes on to elaborate that there was no evidence to support that orotic acid would replace water within the inner sphere of the magnesium and subsequently stated that magnesium bis-orotate tetrahydrate, if bought commercially, would form the described octahydrate in aqueous solution at ambient temperature [84]. Similar findings were produced by Schmidbaur after the synthesis of magnesium bis-anthranalite dehydrate [89]. Schmidbaur further spoke to a similar form of outer-sphere coordination exhibited by citric acid as was initially described by Johnson et al. [90].

Schmidbaur went on to further evaluate the coordination of mandelic acid (mandelate-International Union of Pure and Applied Chemistry (IUPAC): hydroxyl (phenyl) acetic acid), a similar aromatic organic compound (Figure 5) [86,87] to magnesium. Given the structural similarities between orotic acid and mandelic acid, coordinative similarities are to be expected. However, there are four distinct differences between the two acids; the carboxylic acid side chain of mandelic acid is one carbon longer than that of orotic acid and contains a subsequent hydroxyl group, and the benzyl moiety of mandelic acid is devoid of any amines or carbonyls (structure at left).<smiles>O=C(O)C(O)c1ccccc1</smiles>

Figure 5. Illustrated structure of mandelic acid.

Given the structure of mandelic acid, it is assumed that a magnesium complex formed with such a ligand would form a five-member ring structure and would require two mandelic acid ligands for charge balance as the magnesium is divalent and the mandelic acid ligand is only monoanionic. These assumptions coincide with the findings reported by Schmidbaur et al. (Figure 6) [91] 


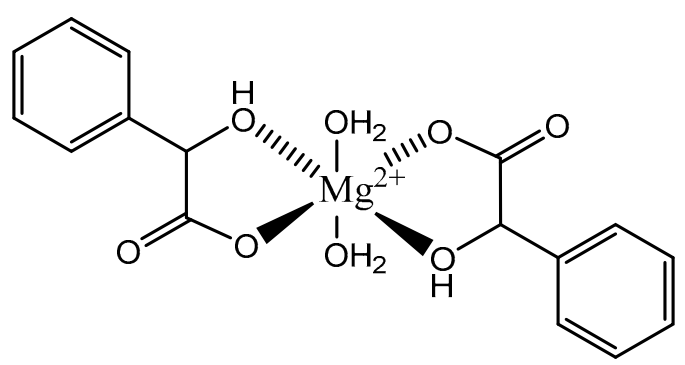

Figure 6. Illustrated structure of the magnesium bis-mandalate dihydrate structure proposed by Schmidbaur et al. [91].

As shown, the mandelic acid ligand coordinates via an $O, O$-bidentate donor set and forms a stable five-member ring. The carboxylic acid of the mandelic acid becomes deprotonated, rendering it a carboxylate, and the backbone hydroxy remains protonated. Overall, the complex is six-coordinate and retains a strongly distorted octahedral geometry [91]. All coordination for the above complex is inner-sphere. Lastly, it should be noted that coordination of alcohol groups is not very common in aqueous magnesium chemistry [91].

The coordination of anthranilic acid (IUPAC-2-aminobenzoic acid-Figure 7) [86,87] to magnesium was also investigated by Schmidbaur et al. [89]. Much like orotic acid, anthranilic acid does not act as a traditional magnesium chelate. In fact, the resulting magnesium anthranilate complex is the product of an extensive hydrogen bond network and is an octahydrate (Figure 8) [89]. As observed in the below illustration, all interactions between anthranilate and magnesium occur via outer-sphere coordination. The complex retains a hexaaquo magnesium core, and the anthranilate ligand coordinates via a series of hydrogen bonds between the amine and carboxylate group [89]. The complex retains a six-coordinate distorted octahedral geometry [89]. Schmidbaur noted that, when heated to $125^{\circ} \mathrm{C}$, the overall complex gave way to two other products-a hexahydrate that loses the interstitial waters, and an anhydrous product of only magnesium and anthranilate- but does not elaborate further as to the structure of these new species [89].<smiles>Nc1ccccc1C(=O)O</smiles>

Figure 7. Structural illustration of anthranilic acid.

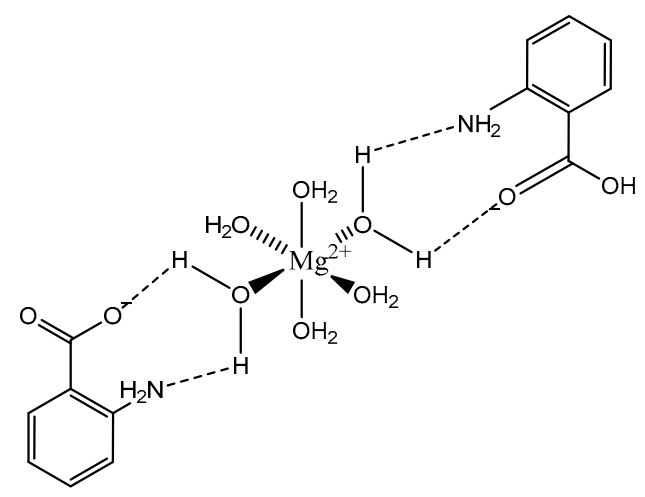

Figure 8. Structural illustration of the magnesium anthranilate structure proposed by Schmidbaur et al. [89]. The structure is devoid of two interstitial waters. 
Of the aromatic magnesium structures studied by Schmidbaur, all three were octahedral, and two formed complexes solely through outer-sphere coordination via an extensive hydrogen bond that is common to magnesium complexes given the high propensity of magnesium to take on water in aqueous media $[2,40]$.

\subsubsection{Formic Acid}

Formic acid (formate; IUPAC: methanoic acid-Figure 9) [86,87] is a naturally occurring carboxylic acid, and it is also the simplest carboxylic acid with the formula $\mathrm{HCOOH}$. It is miscible with water and other polar organic solvents [92]. The conjugate base of formic acid, formate, is a common biproduct of the photo- and electrocatalytic reduction of carbon dioxide $\left(\mathrm{CO}_{2}\right)$ to carbon dioxide (CO) [93-96]. Formic acid is readily derived from almost any plant biomass [97]. Formate is also used as a biomarker for methanol toxicity in the human body [92]. Magnesium formate structures were elucidated by Osaki et al. [98]. Since it only has one moiety that can be deprotonated, the formic acid conjugate base, formate, acts as a monoanion. It is likely the ligand will act as a monodentate ligand, but there is the possibly that it acts as a bidentate ligand given the resulting resonance structure that arises after deprotonation. The structure of magnesium formate described by Osaki et al. [98] is that of a magnesium bis-formate dihydrate (Figure 10).

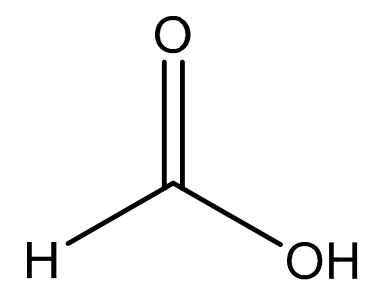

Figure 9. Structure illustration of formic acid.

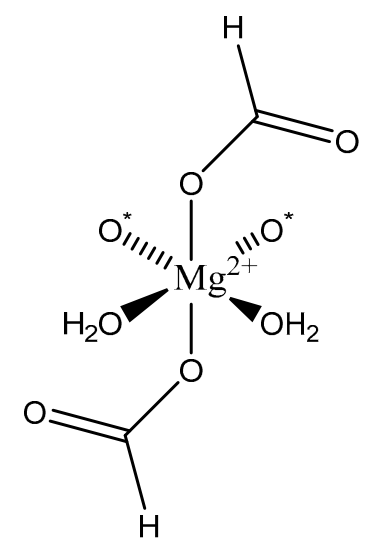

Figure 10. Illustrated structure of the magnesium bis-formate complex reported by Osaki et al. [98].

In this case, the formate acts as a monoanionic monodentate ligand, which subsequently gives rise to the bis-formate chemical composition required for charge balance [98]. The remaining coordination sites are occupied by two waters and two oxygens from adjacent formate ligands [98]. The overall geometry of the complex is six-coordinate octahedral. Although the crystal structure in the solid state highlights two positions being occupied by oxygens from the surrounding formate ligands, undoubtedly, these two positions would be occupied by water in aqueous media, subsequently resulting in a tetrahydrate species rather than a dihydrate. 


\subsubsection{Glycine}

As the simplest amino acid and the only amino acid without a stereocenter [99], glycine (IUPAC: 2-aminoacetic acid-Figure 11) [86,87] was an ideal starting point for the evaluation of biorelevant magnesium chelates. Initial studies to determine the coordination of glycine to magnesium at varying stoichiometries were conducted by Martell et al. [82,83]. Martell showed that, at a 1:1 stoichiometry of magnesium to ligand, only one ligand would coordinate to the magnesium center as a bidentate ligand, subsequently forming an entropically favored, highly stable five-member ring structure, with the remaining coordination sites being occupied by water and the overall complex retaining an octahedral geometry. At a 1:2 magnesium to ligand stoichiometry, it was shown that the magnesium-glycine complex would retain a magnesium bis-glycinate composition, again with the glycines acting as bidentate chelates and forming five-member rings, the remaining coordination sites being occupied by water, and the overall complex having an octahedral geometry (Figure 12). In both cases, the glycine ligand coordinated via inner-sphere coordination.<smiles>NCC(=O)O</smiles>

Figure 11. Structure of glycine.

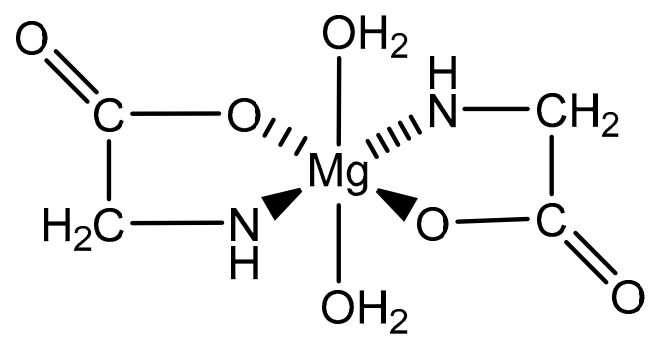

Figure 12. An illustration of the magnesium bis-glycinate dihydrate complex formed from a 1:2 magnesium-glycine stoichiometry $[82,83]$.

\subsubsection{Malic Acid and Maleic Acid}

Malic acid (2-hydroxybutanedioic acid-Figure 13) $[86,87]$ is a dicarboxylic acid that exhibits substantial water solubility and readily impacts $\mathrm{pH}[100,101]$. Given the inherent relationship between $\mathrm{pH}$ and magnesium absorption, malic acid provides the innate capability of buffering $\mathrm{pH}$ in regions of the small bowel where magnesium uptake is most substantial and, as such, is a useful magnesium chelate. Perusal of the literature indicates two described magnesium malate compositions and coordination modes based largely on reaction conditions, stoichiometry, and crystallization methods. One such structure, magnesium malate pentahydrate, was reported by Van Havere [102]. The malic acid acted as a true magnesium chelate (Figure 14)<smiles>O=C(O)C[C@H](O)C(=O)O</smiles>

Figure 13. Structure of malic acid. 


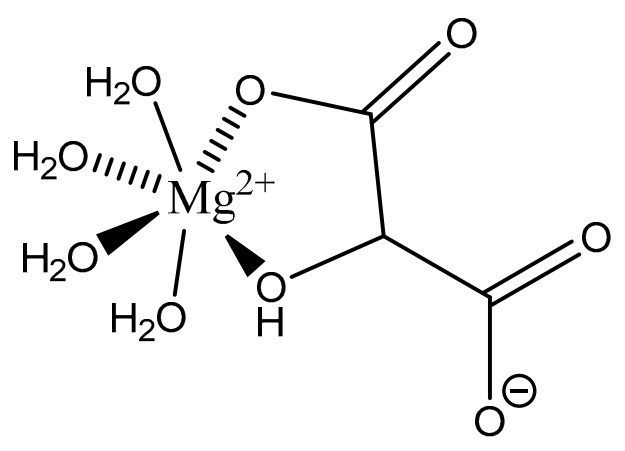

Figure 14. Structural illustration of the magnesium malic acid structure reported by Van Havere [102]. The structure is devoid of interstitial water.

As shown, the magnesium center assumes a six-coordinate, distorted octahedral geometry [102]. The malic acid ligand acts as a bidentate chelate and forms a highly stable five-member ring through one carboxylic acid and the backbone hydroxy group [102]. The remaining four coordination sites are occupied by water [102]. The resulting stoichiometry of the complex is 1:1 (M:L). No counterion is required for charge balance as the malic acid ligand is dianionic. In this case, all coordination is inner-sphere [102]. These findings are in conflict with findings reported in the early 1900s by Groth, who indicated the malic acid ligand acted as a tridentate ligand via an $\mathrm{O}_{3}$ donor set and the overall complex composition was that of a trihydrate [102].

Maleic acid (IUPAC—cis-butenedioic acid—Figure 15) $[86,87]$ is a dicarboxy acid like malic acid. A magnesium hydrogenmaleate structure was reported by Gupta et al. [103]. The structure showed a magnesium bis(hydrogenmalate) hexahydrate composition [103]. In this case, the maleate did not act as a traditional magnesium chelate, instead forming a magnesium complex via outer-sphere coordination to a hexaaquo magnesium core [103]. The hexaaquo magnesium core was six-coordinate and a near-perfect octahedron [103]. The hydrogen maleate coordinated to the hexaaquo magnesium core via a hydrogen bond between the deprotonated carboxylate group and one of the magnesium core waters [103]. The overall stoichiometry of the complex was 1:2 (M:L) and the resulting stoichiometry is what gives the complex overall charge balance, given the divalent magnesium and two maleic acid ligands acting monoanions. The overall structure is depicted in Figure 16.<smiles>O=C(O)CCC(=O)O</smiles>

Figure 15. Structural illustration of maleic acid.

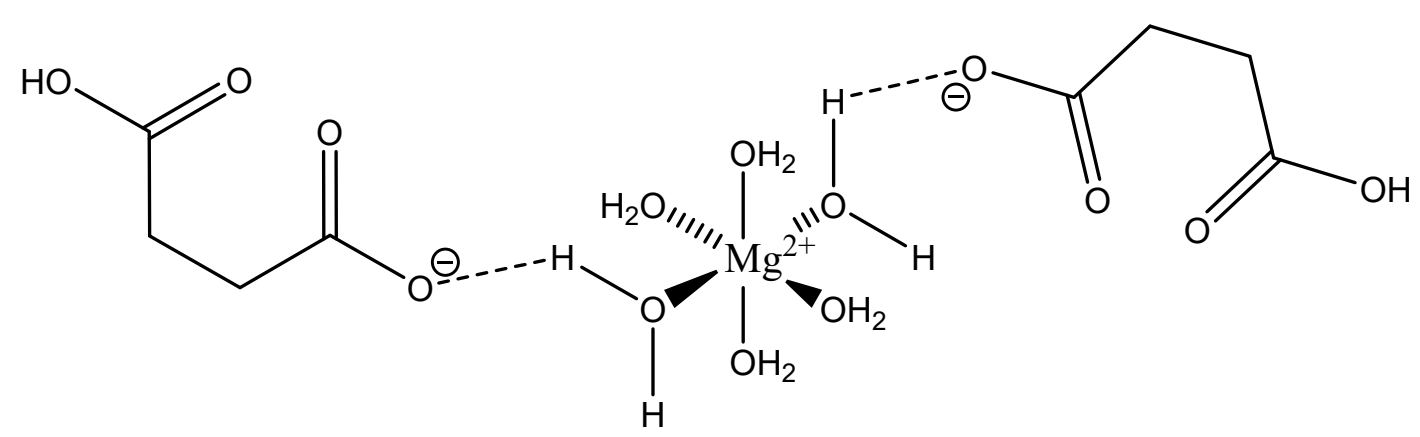

Figure 16. Structural Illustration of the magnesium bis(hydrogenmaleate) hexahydrate structure reported by Gupta et al. [103]. 
It is most likely that this particular species, being complexed only via hydrogen bonding, would exist as the hexaquo magnesium core in aqueous solution.

\subsubsection{Aspartic Acid}

Aspartic acid (aspartate; IUPAC: 2-aminobutanedioic acid-Figure 17) [86,87] is one of the 20 basic amino acids and is a nonessential amino acid, meaning that it is naturally produced by all mammals. Aspartic acid was first described by A. Plisson and E. Henry [104]. Aspartic acid is a dicarboxylic acid with substantial water solubility in aqueous solutions [105], and it has two stereoisomers: L-aspartic acid and D-aspartic acid; these isomers are a result of the changing stereochemistry of the backbone amine. Given their structural likeness, it comes as no surprise that aspartic acid also shows agonistic behavior at glutamate receptors [106]. Discussed at length before, the biorelevant orotic acid can also be synthesized from aspartic acid [107]. Given the biological applications of aspartic acid, it was evaluated as a magnesium chelate in the mid-1980s by Schmidbaur et al. [65]. From strongly alkaline solutions of magnesium aspartate $(\mathrm{pH}>10)$, Schmidbaur determined that the aspartic acid ligand acted as a tridentate ligand with an $\mathrm{N}, \mathrm{O}, \mathrm{O}$ donor set via inner sphere coordination, and the overall magnesium aspartate complex was six-coordinate and retained a 1:1 magnesium to aspartate stoichiometry with octahedral geometry (Figure 18) [65,108].

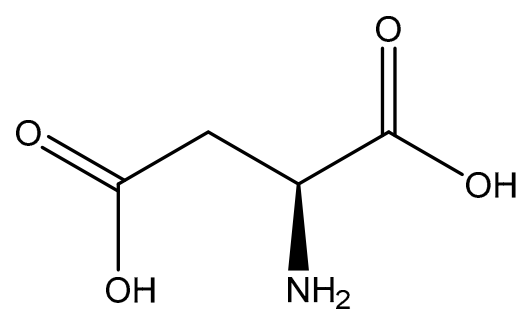

Figure 17. Structure of L-aspartic acid.<smiles>O=C1CC2CC(=O)O[N+](O)(O2)[Y10](O)(O)O1</smiles>

Figure 18. Illustrated structure of magnesium aspartate trihydrate [65].

The inherent charge balance achieved by the above complex comes from the dianionic character of the aspartic acid. Further studies conducted by Schmidbaur et al. would indicate that the synthetic approach to magnesium aspartate complexes greatly impacts the outcome of isolated product. For example, Schmidbaur showed that a magnesium bis(hydrogenasparte) complex was generated in fair yield from the neutralization of magnesium oxide $(\mathrm{MgO})$, magnesium hydroxide $\left(\mathrm{Mg}(\mathrm{OH})_{2}\right)$, and magnesium carbonate $\left(\mathrm{MgCO}_{3}\right)$ [65]. In this case, while both carboxylic acid moieties are deprotonated, the backbone amine remains protonated $\left(-\mathrm{NH}_{3}{ }^{+}\right)$; this, in turn, alters the charge of the aspartic acid ligand from two-minus $(-2)$ to one-minus $(-1)$. This would result in the magnesium center requiring 
two aspartic acid ligands to achieve charge balance, and this occurrence was observed by Schmidbaur et al. (Figure 19) [65,109].

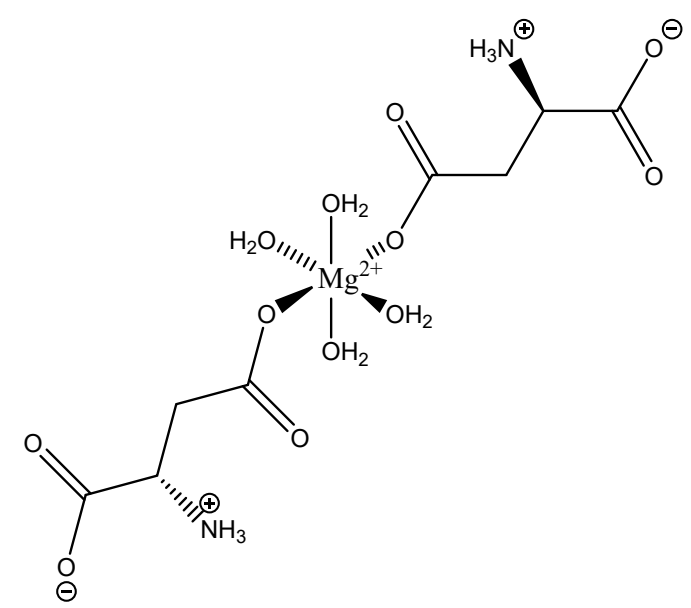

Figure 19. Illustrated structure of the magnesium bis(hydrogenaspartate) tetrahydrate structure reported by Schmidbaur et al. [65,109].

As illustrated, each aspartic acid ligand coordinates through one of the two available carboxylic acid moieties. The charge of the divalent magnesium is balance by the inherent one-minus $(-1)$ charge of each hydrogen aspartate ligand. The one-minus charge of each ligand is the result of the $\mathrm{pH}$ of the synthetic conditions, which results in the protonation of the backbone amine. This protonation of the amine results in a positive charge $(+1)$, and subsequently balances one of the negative charges $(-1)$ from the two carboxylates, thus resulting in a net negative charge (-1) for each ligand [65,109]. The overall one-minus (-1) charge of the aspartate indicates that the divalent magnesium requires two aspartic acid ligands to achieve a charge-balanced complex, and an inherent 1:2 stoichiometry of the reported crystal structure supports this claim [65,109]. In this case, the aspartic acid ligand acts as a monodentate ligand, most likely the result of the backbone amine being protonated, in trans positions, and the overall complex is 6-coordinate with octahedral geometry $[65,109]$. The monodentate character of the aspartic acid ligand also speaks to the balance maintained between entropically favored bidentate complexes, and enthalpically favored complexes with a greater degree of hydration [65,109]. It should be further noted that the crystal structure clearly shows coordination of both the L- and D-aspartic acid isomers; this is accepted given the racemic mix of aspartic acid and the difficulty of isolating the enantiopure isomers [110].

Further studies conducted by Schmidbaur showed that the work-up of aqueous solutions containing $\mathrm{Mg}^{2+}, \mathrm{AspH}^{-}$, and $\mathrm{Cl}^{-}$via spray-drying resulted in yet another magnesium aspartate complex of the composition $\mathrm{Mg}(\mathrm{L}-\mathrm{Asp}) \mathrm{Cl} \cdot 3 \mathrm{H}_{2} \mathrm{O}$ (Figure 20) [65].

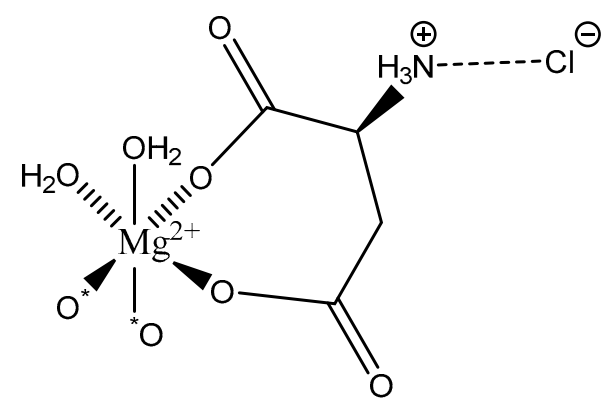

Figure 20. Illustrated structure of the $\mathrm{Mg}(\mathrm{L}-\mathrm{Asp}) \mathrm{Cl} \cdot 3 \mathrm{H}_{2} \mathrm{O}$ reported by Schmidbaur et al. [65]. The structure is devoid of interstitial water that deems the overall complex formation a trihydrate. 
As illustrated, the structure is again six-coordinate octahedral. However, in this case, yet another coordination mode the aspartic acid ligand is observed: bidentate; the ligand coordinates via an $\mathrm{O}, \mathrm{O}$ donor set from both the $\alpha$ - and $\beta$-carboxylic acids and forms an entropically favored seven-member ring. The backbone amine is precluded from magnesium coordination given its protonated state. Under reported synthetic conditions, both carboxylic acid moieties are deprotonated and the backbone amine is protonated [65]. While this should result in an overall one-minus $(-1)$ charge of the ligand and subsequently the requirement of a bis(L-hydrogenaspartate) complex formation, the protonated amine is charge-balanced via hydrogen bonding to the chloride anion resulting in an overall dianionic net charge of the L-hydrogenasparate ligand and a 1:1 stoichiometry of magnesium:-L-hydrogenasparate [65]. $\mathrm{Mg}(\mathrm{L}-\mathrm{Asp}) \mathrm{Cl} \cdot 3 \mathrm{H}_{2} \mathrm{O}$ retains a layered structure and an interstitial water molecule between each layer [65]. Two coordination sites of the magnesium subunit are occupied by water-resulting in an overall trihydrate composition - and the other two sites are occupied by carboxyl oxygens from neighboring units. It should be further noted that only the L-hydrogenaspartate ligand is observed, even though aspartic acid exists as a racemic mix.

Schmidbaur's work with magnesium aspartate complexes illustrates the many available coordination modes of the dicarboxy ligand $[65,109,111]$. Schmidbaur's collective works illustrate that the aspartic acid ligand, under varying synthetic approaches and $\mathrm{pH}$ ranges, will act as a mono-, bi-, and tridentate ligand $[65,108,109]$. However, regardless of the coordination mode of the ligand, the overall magnesium complex will assume six-coordinate octahedral geometry and achieve charge balance. Furthermore, resulting magnesium aspartate complexes are the product of a delicate balance between enthalpic and entropic terms [65].

\subsubsection{Glutamic Acid}

Glutamic acid (glutamate; IUPAC: 2-aminopentanedioic acid-Figure 21) [86,87] differs from aspartic acid by a single methylene unit and is also a dicarboxylic acid with two stereoisomers (L-glutamate and D-glutamate) [112]. It was first discovered in 1866 by Ritthausen, and the chemical composition was later confirmed [113]. In addition to use in protein synthesis, glutamic acid biological is also a neurotransmitter, being responsible for mediating most of the fast excitatory neurotransmission in the central nervous system (CNS) [114]. Furthermore, approximately $80-90 \%$ of receptors in the brain are glutamatergic [114,115]. Glutamic acid is also a precursor for $\gamma$-aminobutyric acid (GABA) and is a constituent of glutathione [114]. As such, glutamic acid is of substantial biological importance, and it is an ideal candidate for magnesium coordination and subsequent supplementation.

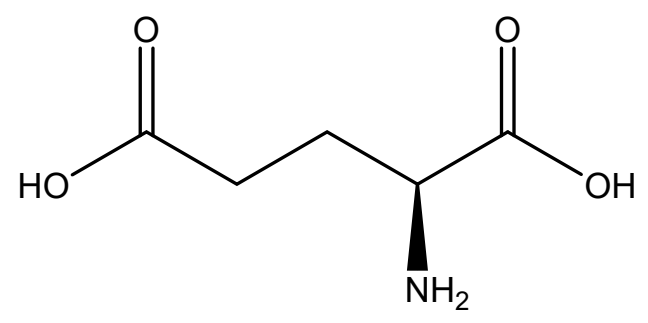

Figure 21. Structural illustration of L-glutamic acid.

Studies into the coordination of glutamic acid to magnesium were conducted by Schmidbaur et al. [65]. Schmidbaur reports that, from alkaline potassium hydroxide $(\mathrm{KOH})$ solutions of magnesium glutamate, $\mathrm{Mg}(\mathrm{L}-\mathrm{Glu})$ can be obtained as both a di- and tetrahydrate $\left(2 \mathrm{H}_{2} \mathrm{O}, \cdot 4 \mathrm{H}_{2} \mathrm{O}\right)[65,111]$. However, Schmidbaur only reported on the crystallized structure of the tetrahydrate (Figure 22) $[65,111]$. 
<smiles>O=C(O)CCC1N[Y16](O)(O)OC1=O</smiles>

Figure 22. Structural illustration of $\mathrm{Mg}(\mathrm{L}-\mathrm{Glu}) \cdot 4 \mathrm{H}_{2} \mathrm{O}$ reported by Schmidbaur et al. $[65,111]$.

As illustrated, the glutamic acid ligand coordinates as an $N, O(\alpha)$-bidentate ligand via the $\alpha$-carboxylate and the neighboring amine. In this case, the complex forms a five-member ring conformation with the glutamic acid ligand and chooses to forgo coordination to the $\gamma$-carboxylate; charge balance is still achieved due to the dianionic character of the glutamic acid ligand. This is interesting because aspartic acid and glutamic acid differ by only one carbon, and aspartic acid adopts a seven-member ring structure. It is likely the glutamic acid ligand adopts a five-member ring structure in favor of an eight-member ring structure due to differences in entropy-a claim supported by Schmidbaur $[65,111]$. The $\gamma$-carboxylate, while not participating in binding to the metal, does, however, participate in the extensive hydrogen bond network surrounding the complex in aqueous solution. In this case, the remaining magnesium coordination sites are occupied by four water molecules. The $\mathrm{Mg}(\mathrm{L}-\mathrm{Glu}) \cdot 4 \mathrm{H}_{2} \mathrm{O}$ retains a six-coordinate octahedral geometry and all coordination is inner-sphere. Schmidbaur was unsuccessful in crystallizing the dihydrate magnesium glutamate species, but it is likely that the reported species, with a higher degree of solvation, is most relevant in aqueous solution $[65,111]$.

\subsubsection{Citric Acid}

Citric Acid (citrate; IUPAC: 2-hydroxypropane-1,2,3-tricarboxylic acid-Figure 23) [86,87] is a tricarboxylic acid ligand with multiple Lewis bases. It is naturally occurring and was first isolated from lemon juice [116]. Perhaps most notably, citric acid is utilized during cellular respiration as part of the citric acid (Krebs) cycle [117]. Citric acid is used as a metal ion sequestrant and also shows appreciable water solubility [118]. As such, citric acid is a promising option as a magnesium coordinate ligand. Studies into the structure of magnesium citric acid complexes were reported on by Carroll $\mathrm{K}$. Johnson in the early 1960s. Johnson reported on the structure of a magnesium citrate decahydrate complex (Figure 24) [90]; while a decahydrate may seem unreasonable, it is very reasonable given magnesium's high propensity for hydration water and its extensive hydration sphere [2]. Highly solvated magnesium citrate complexes (a 14-hydrate) were also reported by Mansour et al. [119].

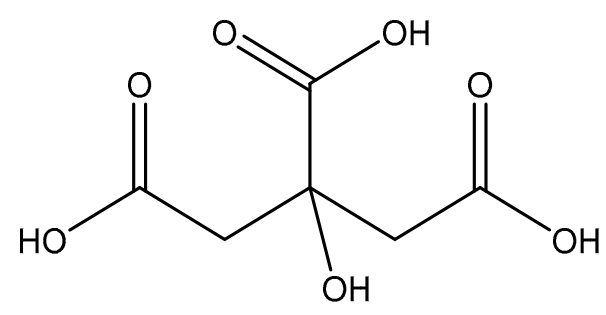

Figure 23. Illustrated structure of citric acid. 


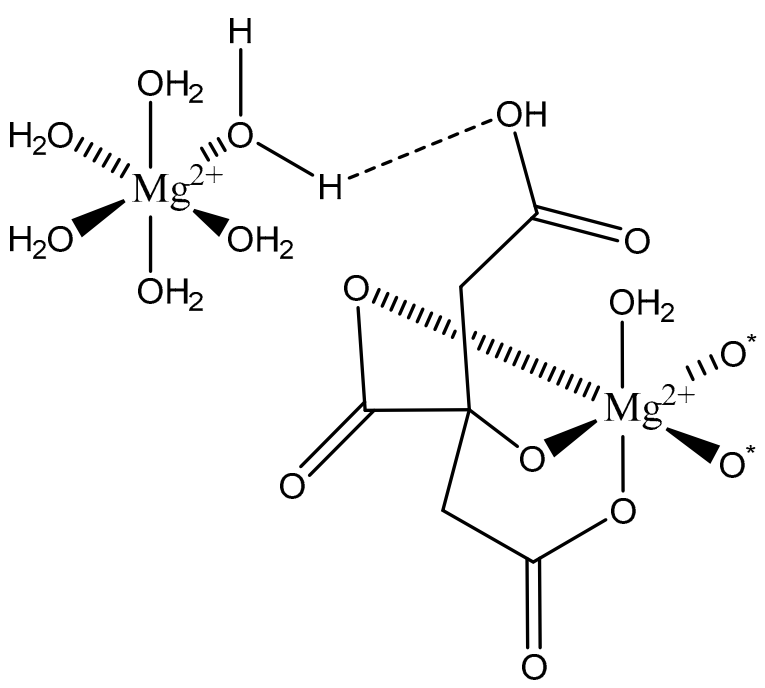

Figure 24. Illustrated structure representative of the structure reported by Johnson [90]. The structure does not illustrate interstitial waters. $\mathrm{O}^{*}$ indicates contributed oxygen atoms from surrounding citrate molecules.

The structure reported by Johnson shows the crystal structure to contain two subunits (binuclear). The first subunit is that of a hexaaquo magnesium species (left), much like the species described by Weston [40], and a magnesium citrate species (right). In this case, the citrate does not participate in direct chelation to the magnesium at the center of the magnesium hexaaquo species, but does contribute a hydrogen bond [90] likened to that of outer-sphere coordination [40]. In the case of the magnesium at the center of the magnesium citrate complex, the citrate ligand coordinates via an $\mathrm{O}, \mathrm{O}, \mathrm{O}$-tridentate donor set; all coordination is inner-sphere. The citrate forms an entropically favored six-member ring via one terminal carboxylate group and the central hydroxy group and a second entropically favored five-member ring via the central hydroxy group and the central carboxylate group [90]. It seems peculiar that the citric acid ligand would forgo the symmetry of two six-membered rings, but it stands to reason given the tendency of magnesium to form stable five-member ring structures with "hard" base donors such as that of magnesium bis-glycinate [82]. Further evaluation of the structure also indicates that both magnesium centers are six-coordinate and retain octahedral geometry; all coordinate positions of the hexaaquo magnesium are occupied by waters, and the positions of the magnesium citrate complex that are not occupied by the citric acid ligand are occupied by one water and two oxygens from the carboxylates of neighboring citrate molecules. The two metal centers of the crystal structure indicate a linkage via hydrogen bonding between the non-coordinated carboxylic acid of the citric acid ligand and one of the waters from the hexaaquo magnesium species.

\section{Summary}

The coordination chemistry of biorelevant magnesium ligands is a sparse field. Of the 20 basic amino acids, only four were reported as magnesium chelate ligands and subsequently elucidated structurally; only a small percentage of the possibilities of biorelevant magnesium complexes were revealed or utilized. In general, biorelevant magnesium complexes will assume a six-coordinate octahedral geometry and will almost always employ "hard" acids (N, O, etc.) as donors from the coordinate ligands. Coordinate ligands can assume many coordinate modes (mono-, bi-, or tridentate), and may be inner- or outer-sphere. For structures already solved, findings are reported in Table 5. 
Table 5. Complete summary of all reviewed complexes including ligand coordination modes, complex coordination, and complex geometry. This table does not include those complexes reported by Yang et al. Yang supplies a full summary in his initial work [120]. The asterisk $\left(^{*}\right)$ denotes a shorthand to define complex geometry as either octahedral (O), distorted octahedral (D.O.), pseudo-octahedral (P.O.), tetrahedral (T), distorted tetrahedral (D.T.), or square planar (S.P.). The pound (\#) indicates the coordination number of the described magnesium complex (i.e., the species is six-coordinate).

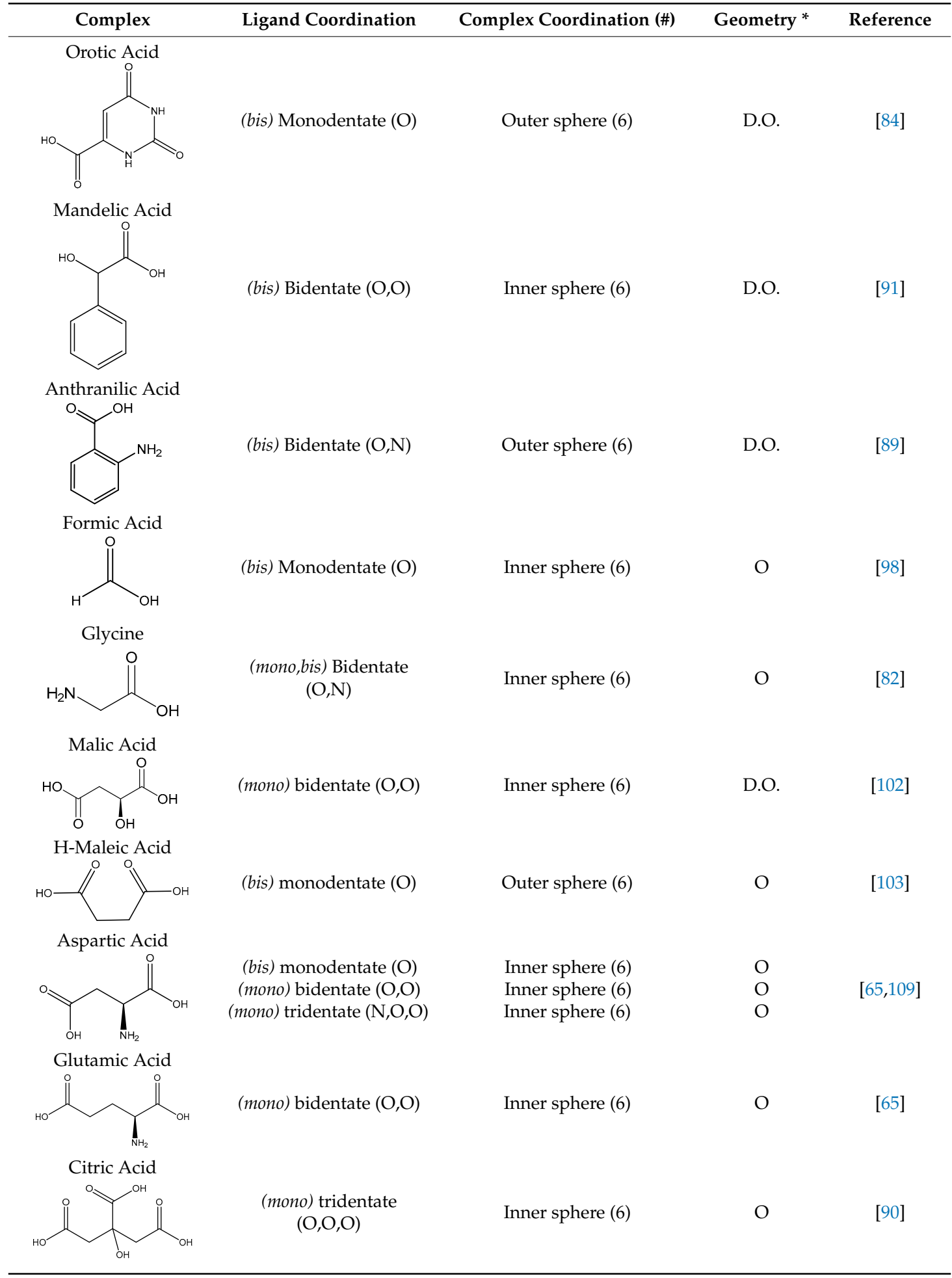


The coordination of biorelevant ligands to magnesium is altered by slight changes in many variables; these variables include protonated states of the ligand as a result of $\mathrm{pH}$, the flexibility of the ligand, organic or aqueous media, and whether the entropy of a multidentate coordination of the ligands is favored over enthalpy. As is the case with many of the described complexes produced in aqueous media, coordination of the ligand occurs as a series of hydrogen bonds to hexaaquo magnesium core, suggesting that hydration of magnesium and the subsequent enthalpy is favored. However, in other cases, if the ligand has the capability to form stable five-, six-, or seven-member rings, a complex may be produced with the ligand acting as a bi-, tri-, or tetradentate ligand that is more entropically favored. These variables can be controlled synthetically. In addition, software was developed, which is effective at predicting complexes of these types of reactions. MINTEQ ${ }^{\mathrm{TM}}$ is an open-source software platform that determines speciation based upon reaction conditions such as temperature, $\mathrm{pH}$, ionic strength, and stoichiometries during synthesis, based in large part on speciation experiments conducted by Martell et al. [82,121]. Such programs are an invaluable resource for understanding biorelevant magnesium complex coordination chemistry in aqueous media.

Author Contributions: This manuscript was written by all authors, and all authors read and agreed to the published version of the manuscript.

Funding: This review received no external funding.

Conflicts of Interest: R.P.D. is a scientific advisory board member and receives funding from Balchem Corp. (New Hampton, NY, USA).

\section{References}

1. De Baaij, J.H.F.; Hoenderop, J.G.J.; Bindels, R.J.M. Magnesium in Man: Implications for Health and Disease. Physiol. Rev. 2015, 95, 1-46. [CrossRef] [PubMed]

2. Jahnen-Dechent, W.; Ketteler, M. Magnesium Basics. Clin. Kidney J. 2012, 5, 3-14. [CrossRef] [PubMed]

3. Geiger, H.; Wanner, C. Magnesium in Disease. Clin. Kidney J. 2012, 5, 25-38. [CrossRef] [PubMed]

4. Alfrey, A.C.; Miller, N.L.; Trow, R. Effect of Age and Magnesium Depletion on Bone Magnesium Pools in Rats. J. Clin. Investig. 1974, 54, 1074-1081. [CrossRef] [PubMed]

5. Rude, R.K.; Gruber, H.E. Magnesium Deficiency and Osteoporosis: Animal and Human Observations. J. Nutr. Biochem. 2004, 15, 710-716. [CrossRef]

6. $\quad$ Rude, R.K.; Gruber, H.E.; Norton, H.J.; Wei, L.Y.; Frausto, A.; Mills, B.G. Bone Loss Induced by Dietary Magnesium Reduction to $10 \%$ of the Nutrient Requirement in Rats Is Associated with Increased Release of Substance P and Tumor Necrosis Factor- $\alpha$. J. Nutr. 2004, 134, 79-85. [CrossRef]

7. Chiu, T.K.; Dickerson, R.E. $1 \AA$ Crystal Structures of B-DNA Reveal Sequence-Specific Binding and Grove-Specific Bending of DNA by Magnesium and Calcium. J. Mol. Biol. 2000, 303, 111. [CrossRef]

8. Serra, M.J.; Baird, J.D.; Dale, T.; Fey, B.L.; Retatagos, K.; Westhof, E. Effects of Magnesium Ions on the Stabilization of RNA Oligomers of Defined Structures. RNA 2002, 8, 307-323. [CrossRef]

9. Misra, V.K.; Draper, D.E. On the Role of Magnesium Ions in RNA Stability. Biopolymers 1998, 48, $113-135$. [CrossRef]

10. Lindahl, T.; Adams, A.; Fresco, J.R. Renaturation of Transfer Ribonucleic Acids through Site Binding of Magnesium. Proc. Natl. Acad. Sci. USA 1966, 55, 941-948. [CrossRef]

11. Mills, B.J.; Lindeman, R.D.; Lang, C.A. Magnesium Deficiency Inhibits Biosynthesis of Blood Glutathione and Tumor Growth in Rat. Proc. Soc. Exp. Biol. Med. 1986, 181, 326-332. [CrossRef] [PubMed]

12. Schwalfenberg, G.K.; Genuis, S.J. The Importance of Magnesium in Clinical Healthcare. Scientifica 2017, 2017, 1-14. [CrossRef] [PubMed]

13. Sreedhara, A.; Cowan, J.A. Structural and Catalytic Roles for Divalent Magnesium in Nucleic Acid Biochemistry. BioMetals 2002, 15, 211-223. [CrossRef]

14. Magnesium Fact Sheet for Health Professionals. Available online: https:/ods.od.nih.gov/factsheets/ Magnesium-HealthProfessional/ (accessed on 21 May 2020).

15. Rosanoff, A.; Weaver, C.M.; Rude, R.K. Suboptimal Magnesium Status in the United States: Are the Health Consequences Underestimated? Nutr. Rev. 2012, 70, 153-164. [CrossRef] 
16. Moshfegh, A.; Goldman, J.; Cleveland, L. What We Eat in America, NHANES 2001-2002: Usual Nutrient Intakes from Food Compared to Dietary Reference Intakes. Available online: https://www.ars.usda.gov/ research/publications/publication/?seqNo115=184176 (accessed on 11 July 2020).

17. King, D.E.; Mainous, A.G.; Geesey, M.E.; Egan, B.M.; Rehman, S. Magnesium Supplement Intake and C-Reactive Protein Levels in Adults. Nutr. Res. 2006, 26, 193-196. [CrossRef]

18. Chan, K.H.K.; Chacko, S.A.; Song, Y.; Cho, M.; Eaton, C.B.; Wu, W.-C.H.; Liu, S. Genetic Variations in Magnesium-Related Ion Channels May Affect Diabetes Risk among African American and Hispanic American Women. J. Nutr. 2015, 145, 418-424. [CrossRef]

19. Razzaque, M.S. Magnesium: Are We Consuming Enough? Nutrients 2018, 10, 1863. [CrossRef]

20. Li, H.; Sun, S.; Chen, J.; Xu, G.; Wang, H.; Qian, Q. Genetics of Magnesium Disorders. Kidney Dis. 2017, 3, 85-97. [CrossRef]

21. Gile, J.; Ruan, G.; Abeykoon, J.; McMahon, M.M.; Witzig, T. Magnesium: The Overlooked Electrolyte in Blood Cancers? Blood Rev. 2020, in press. [CrossRef]

22. Workinger, J.L.; Doyle, R.P.; Bortz, J. Challenges in the Diagnosis of Magnesium Status. Nutrients 2018, 10, 1202. [CrossRef]

23. Costello, R.; Wallace, T.; Rosanoff, A. Nutrient Information: Magnesium. Adv. Nutr. Int. Rev. J. 2016, 7, 199-201. [CrossRef]

24. Horner, S.M. Efficacy of Intravenous Magnesium in Acute Myocardial Infarction in Reducing Arrhythmias and Mortality: Meta-Analysis of Magnesium in Acute Myocardial Infarction. Circulation 1992, 86, 774-779. [CrossRef]

25. Mizushima, S.; Cappuccio, F.P.; Nichols, R.; Elliott, P. Dietary Magnesium Intake and Blood Pressure: A Qualitative Overview of the Observational Studies. J. Hum. Hypertens. 1998, 12, 447-453. [CrossRef]

26. Kass, L.; Weekes, J.; Carpenter, L. Effect of Magnesium Supplementation on Blood Pressure: A Meta-Analysis. Eur. J. Clin. Nutr. 2012, 66, 411-418. [CrossRef]

27. DiNicolantonio, J.J.; O'Keefe, J.H.; Wilson, W. Subclinical Magnesium Deficiency: A Principal Driver of Cardiovascular Disease and a Public Health Crisis. Open Hear. 2018, 5, e000668. [CrossRef]

28. Gant, C.M.; Soedamah-Muthu, S.S.; Binnenmars, S.H.; Bakker, S.J.L.; Navis, G.; Laverman, G.D. Higher Dietary Magnesium Intake and Higher Magnesium Status Are Associated with Lower Prevalence of Coronary Heart Disease in Patients with Type 2 Diabetes. Nutrients 2018, 10, 307. [CrossRef]

29. Cappuccio, F.P. Sodium, Potassium, Calcium and Magnesium and Cardiovascular Risk. Eur. J. Prev. Cardiol. 2000, 7, 1-3. [CrossRef]

30. Altura, B.M.; Altura, B.T. Tension Headaches and Muscle Tension: Is There a Role for Magnesium? Med. Hypotheses 2001, 57, 705-713. [CrossRef]

31. Hayhoe, R.P.G.; Lentjes, M.A.H.; Luben, R.N.; Khaw, K.T.; Welch, A.A. Dietary Magnesium and Potassium Intakes and Circulating Magnesium Are Associated with Heel Bone Ultrasound Attenuation and Osteoporotic Fracture Risk in the EPIC-Norfolk Cohort Study. Am. J. Clin. Nutr. 2015, 102, 376-384. [CrossRef]

32. Classen, H.-G.; Kisters, K. Magnesium and Osteoporosis. Trace Elem. Electrolytes 2017, 34, $100-103$. [CrossRef]

33. Brauman, J.; Schoutens, A. Bone Mineral Content of the Radius: Good Correlations with Physicochemical Determinations in Iliac Crest Trabecular Bone of Normal and Osteoporotic Subjects. Metabolism. 1981, 30, 57-62.

34. Sales, C.H.; Pedrosa, L.d.F.C. Magnesium and Diabetes Mellitus: Their Relation. Clin. Nutr. 2006, 25, 554-562. [CrossRef]

35. Crook, M.; Couchman, S.; Tutt, P.; Amiel, S.; Swaminathan, R. Erythrocyte, Plasma Total, Ultrafiltrable and Platelet Magnesium in Type 2 (Non-Insulin Dependent) Diabetes Mellitus. Diabetes Res. 1994, 27, 73-79. [PubMed]

36. Guerrera, M.; Volpe, S.; Mao, J. Therapeutic Uses of Magnesium. Am. Fam. Physician 2009, 80, $157-162$.

37. Perry, D.L. Handbook of Inorganic Compounds, 2nd ed.; CRC Press: Boca Raton, FL, USA, 2011.

38. Cotton, F.A.; Wilkinson, G. Advanced Inorganic Chemistry, 4th ed.; John Wiley \& Sons; Inc.: New York, NY, USA, 1980.

39. Smith, P.W.G.; Tatchell, A.R. The Synthetic Uses of Grignard Reagents, $\beta$-Keto Esters and Diethyl Malonate. Fundam. Aliphatic Chem. 1965, 216-231. [CrossRef]

40. Weston, J. Biochemistry of Magnesium; John Wiley \& Sons, Ltd.: New York, NY, USA, 2009. 
41. Erdman, J.W.; Macdonald, I.A.; Zeisel, S.H. Present Knowledge in Nutrition, 10th ed.; John Wiley \& Sons, Ltd.: Ames, IA, USA, 2012.

42. Elin, R.J. Magnesium Metabolism in Health and Disease. Disease-A-Month 1988, 34, 166-218. [CrossRef]

43. Elin, R.J. Assessment of Magnesium Status for Diagnosis and Therapy. Magnes. Res. 2010, 23, $194-198$.

44. Vormann, J. Magnesium: Nutrition and Metabolism. Mol. Asp. Med. 2003, 24, 27-37. [CrossRef]

45. Kroll, M.H.; Elin, R.J. Relationships between Magnesium and Protein Concentrations in Serum. Clin. Chem. 1985, 31, 244-246. [CrossRef]

46. Thongon, N.; Krishnamra, N. Apical Acidity Decreases Inhibitory Effect of Omeprazole on Mg2+ Absorption and Claudin-7 and -12 Expression in Caco-2 Monolayers. Exp. Mol. Med. 2012, 44, 684-693. [CrossRef]

47. Nugent, S.G.; Kumar, D. Intestinal Luminal PH in Inflammatory Bowel Disease: Possible Determinants and Implications for Therapy with Aminosalicylates and Other Drugs. Gut 2001, 48, 571-577. [CrossRef]

48. Heijnen, A.M.P.; Brink, E.J.; Lemmens, A.G.; Beynen, A.C. Ileal PH and Apparent Absorption of Magnesium in Rats Fed on Diets Containing Either Lactose or Lactulose. Br. J. Nutr. 1993, 70, 747-756. [CrossRef]

49. Sasaki, Y.; Hada, R.; Nakajima, H.; Fukuda, S.; Munakata, A. Improved Localizing Method of Radiopill in Measurement of Entire Gastrointestinal PH Profiles: Colonic Luminal PH in Normal Subjects and Patients with Crohn's Disease. Am. J. Gastroenterol. 1997, 92, 114-118.

50. Evans, D.F.; Pye, G.; Bramley, R.; Clark, A.G.; Dyson, T.J.; Hardcastle, J.D. Measurement of Gastrointestinal PH Profiles in Normal Ambulant Human Subjects. Gut 1988, 29, 1035-1041. [CrossRef]

51. Irving, J.D. PH-Profile of Gut as Measured by Radiotelemtry Capsule. Br. Med. J. 1972, 2, $104-106$.

52. Press, A.G.; Hauptmann, I.A.; Hauptmann, L.; Fuchs, B.; Fuchs, M.; Ewe, K.; Ramadori, G. Gastrointestinal PH Profiles in Patients with Inflammatory Bowel Disease. Aliment. Pharmacol. Ther. 1998, 12, 673-678. [CrossRef]

53. Ewe, K.; Schwartz, S.; Petersen, S.; Press, A.G. Inflammation Does Not Decrease Intraluminal PH in Chronic Inflammatory Bowel Disease. Dig. Dis. Sci. 1999, 44, 1434-1439. [CrossRef]

54. Maqbool, S.; Parkman, H.P.; Friedenberg, F.K. Wireless Capsule Motility: Comparison of the SmartPill ${ }^{\circledR}$ GI Monitoring System with Scintigraphy for Measuring Whole Gut Transit. Dig. Dis. Sci. 2009, 54, 2167-2174. [CrossRef]

55. Rubin, D.T.; Bunnag, A.P.; Surma, B.L.; Mikolajczyk, A. M1097 Measurement of Lumenal PH in Patients with Mildly to Moderately Active UC: A Pilot Study Using SmartPill PH.Ptm. Gastroenterology 2009, 136, A-349. [CrossRef]

56. Lalezari, D. Gastrointestinal PH Profile in Subjects with Irritable Bowel Syndrome. Ann. Gastroenterol. 2012, 25, 333-337.

57. Van Der Schaar, P.J.; Dijksman, J.F.; Broekhuizen-De Gast, H.; Shimizu, J.; Van Lelyveld, N.; Zou, H.; Iordanov, V.; Wanke, C.; Siersema, P.D. A Novel Ingestible Electronic Drug Delivery and Monitoring Device. Gastrointest. Endosc. 2013, 78, 520-528. [CrossRef]

58. Fallingborg, J.; Christensen, L.A.; Ingeman-Nielsen, M.; Jacobsen, B.A.; Abildgaard, K.; Rasmussen, H.H. PH-Profile and Regional Transit Times of the Normal Gut Measured by a Radiotelemetry Device. Aliment. Pharmacol. Ther. 1989, 3, 605-614. [CrossRef]

59. Fallingborg, J.; Christensen, L.A.; Jacobsen, B.A. Very Low Intraluminal Colonic PH in Patients with Active Ulcerative Colitis. Dig. Dis. Sci. 1993, 38, 1989-1993. [CrossRef]

60. Fallingborg, J.; Pedersen, P.; Jacobsen, B.A. Small Intestinal Transit Time and Intraluminal PH in Ileocecal Resected Patients with Crohn's Disease. Dig. Dis. Sci. 1998, 43, 702-705. [CrossRef]

61. Thongon, N.; Krishnamra, N. Omeprazole Decreases Magnesium Transport across Caco-2 Monolayers. World J. Gastroenterol. 2011, 17, 1574-1583. [CrossRef]

62. Bohn, T. Dietary Factors Influencing Magnesium Absorption in Humans. Curr. Nutr. Food Sci. 2008, 4, 53-72. [CrossRef]

63. Schuchardt, J.P.; Hahn, A. Intestinal Absorption and Factors Influencing Bioavailability of Magnesium- An Update. Curr. Nutr. Food Sci. 2017, 13, 260-278. [CrossRef]

64. Iwanaga, K.; Kato, S.; Miyazaki, M.; Kakemi, M. Enhancing the Intestinal Absorption of Poorly Water-Soluble Weak-Acidic Compound by Controlling Local PH. Drug Dev. Ind. Pharm. 2013, 39, 1887-1894. [CrossRef]

65. Schmidbaur, H.; Classen, H.G.; Helbig, J. Aspartic and Glutamic Acid as Ligands to Alkali and Alkaline-Earth Metals: Structural Chemistry as Related to Magnesium Therapy. Angew. Chem. Int. Ed. Engl. 1990, 29, 1090-1103. [CrossRef] 
66. Kanunnikova, O.M.; Aksenova, V.V.; Karban, O.V.; Muhgalin, V.V.; Senkovski, B.V.; Ladjanov, V.I. Mechanical Activation Effect on Structure, Physicochemical, and Biological Properties of Potassium/Magnesium Orotates. IOP Conf. Ser. Mater. Sci. Eng. 2018, 283, 012004. [CrossRef]

67. Younes, H.; Demigné, C.; Rémésy, C. Acidic Fermentation in the Caecum Increases Absorption of Calcium and Magnesium in the Large Intestine of the Rat. Br. J. Nutr. 2005, 75, 301-314. [CrossRef]

68. Fine, K.D.; Santa Ana, C.A.; Porter, J.L.; Fordtran, J.S. Intestinal Absorption of Magnesium from Food and Supplements. J. Clin. Investig. 1991, 88, 396-402. [CrossRef]

69. Schuette, S.A.; Ziegler, E.E.; Nelson, S.E.; Janghorbani, M. Feasibility of Using the Stable Isotope $25 \mathrm{Mg}$ to Study Mg Metabolism in Infants. Pediatr. Res. 1990, 27, 36-40. [CrossRef]

70. Sabatier, M.; Grandvuillemin, A.; Kastenmayer, P.; Aeschliman, J.M.; Bouisset, F.; Arnaud, M.J.; Dumoulin, G.; Berthelot, A. Influence of the Consumption Pattern of Magnesium from Magnesium-Rich Mineral Water on Magnesium Bioavailability. Br. J. Nutr. 2011, 106, 331-334. [CrossRef]

71. Coudray, C.; Feillet-Coudray, C.; Rambeau, M.; Tressol, J.C.; Gueux, E.; Mazur, A.; Rayssiguier, Y. The Effect of Aging on Intestinal Absorption and Status of Calcium, Magnesium, Zinc, and Copper in Rats: A Stable Isotope Study. J. Trace Elem. Med. Biol. 2006, 20, 73-81. [CrossRef]

72. Mühlbauer, B.; Schwenk, M.; Coram, W.M.; Antonin, K.H.; Etienne, P.; Bieck, P.R.; Douglas, F.L. Magnesium-L-Aspartate- $\mathrm{HCl}$ and Magnesium-Oxide: Bioavailability in Healthy Volunteers. Eur. J. Clin. Pharmacol. 1991, 40, 437-438. [CrossRef]

73. Firoz, M.; Graber, M. Bioavallability of US Commercial Magnesium Preparations. Magnes. Res. 2001, 14, 257-262.

74. Kappeler, D.; Heimbeck, I.; Herpich, C.; Naue, N.; Höfler, J.; Timmer, W.; Michalke, B. Higher Bioavailability of Magnesium Citrate as Compared to Magnesium Oxide Shown by Evaluation of Urinary Excretion and Serum Levels after Single-Dose Administration in a Randomized Cross-over Study. BMC Nutr. 2017, 3, 7. [CrossRef]

75. Ropp, R.C. Group 16 (O, S, Se, Te) Alkaline Earth Compounds; Elsevier: Philadelphia, PA, USA, 2013.

76. Clynne, M.A.; Potter, R.W. Solubility of Some Alkali and Alkaline Earth Chlorides in Water at Moderate Temperatures. J. Chem. Eng. Data 1979, 24, 338-340. [CrossRef]

77. McCarty, M.F.; Calif, S.D. Magnesium Taurate and Other Mineral Taurates. U.S. Patent 5,582,839, 10 December 1996.

78. Apelblat, A.; Manzurola, E. Solubilities of O-Acetylsalicylic, 4-Aminosalicylic, 3, 5-Dinitrosalicylic, and p-Toluic Acid, and Magnesium-DL-Aspartate in Water from T = (278 to 348) K. J. Chem. Thermodyn. 1999, 31, 85-91. [CrossRef]

79. Liu, G.; Mao, F. Slow Release Magnesium Composition and Uses Thereof. U.S. Patent 8,377,473, 19 February 2013.

80. Younes, M.; Aggett, P.; Aguilar, F.; Crebelli, R.; Dusemund, B.; Filipič, M.; Frutos, M.J.; Galtier, P.; Gundert-Remy, U.; Kuhnle, G.G.; et al. Evaluation of Di-Magnesium Malate, Used as a Novel Food Ingredient and as a Source of Magnesium in Foods for the General Population, Food Supplements, Total Diet Replacement for Weight Control and Food for Special Medical Purposes. EFSA J. 2018, 16, e05292. [PubMed]

81. Hartle, J.; Ashmead, S.D.; Kreitlow, R. Dimetal Hydroxy Malates. U.S. Patent 6,706,904, 16 March 2004.

82. Murphy, C.B.; Martell, A.E. Metal Chelates of Glycine and Glycine Peptides. J. Biol. Chem. 1957, 226, 37-50.

83. LEAF, G. Metal Chelates. Nature 1965, 207, 564-565. [CrossRef]

84. Bach, I.; Kumberger, O.; Schmidbaur, H. Orotate Complexes. Synthesis and Crystal Structure of Lithium Orotate (-I) Monohydrate and Magnesium Bis [Orotate (-I)] Octahydrate. Chem. Ber. 1990, 123, 2267-2271. [CrossRef]

85. Haynes, W.M. CRC Handbook of Chemistry \& Physics, 91st ed.; CRC Press: Boca Raton, FL, USA, 2010.

86. Hartshorn, R.M.; Hellwich, K.H.; Yerin, A.; Damhus, T.; Hutton, A.T. Brief Guide to the Nomenclature of Inorganic Chemistry. Pure Appl. Chem. 2015, 87, 1039-1049. [CrossRef]

87. Leigh, G.J.; Favre, H.A.; Metanomski, W.V. Principles of Chemical Nomenclature. In A Guide to IUPAC Recommendations; Leigh, G.J., Ed.; Blackwell Science Ltd.: Oxford, UK, 1999; p. 42.

88. Michelson, M. A New Ribose Nucleoside from Neurospora; “Orotidine”. Proc. Natl. Acad. Sci. USA 1951, 37, 396-399. [CrossRef]

89. Wiesbrock, F.; Schier, A.; Schmidbaur, H. Magnesium Anthranilate Dihydrate. Z. Naturforsch. B 2002, 57, 251-254. [CrossRef] 
90. Johnson, C.K. X-Ray Crystal Analysis of the Substrates of Aconitase. V. Magnesium Citrate Decahydrate. Acta Cryst. 1965, 18, 1004-1018. [CrossRef] [PubMed]

91. Schmidt, M.; Schier, A.; Schmidbaur, H. Magnesium Bis [D (-)-Mandelate] Dihydrate and Other Alkaline Earth, Alkali, and Zinc Salts of Mandelic Acid. Zeitschrift fur Naturforsch. Sect. B J. Chem. Sci. 1998, 53, 1098-1102. [CrossRef]

92. Hietala, J. Formic Acid; Wiley-VCH Verlag GmbH \& Co.: Weinheim, Germany, 2016.

93. Paul, A.; Connolly, D.; Schulz, M.; Pryce, M.T.; Vos, J.G. Effect of Water during the Quantitation of Formate in Photocatalytic Studies on CO 2 Reduction in Dimethylformamide. Inorg. Chem. 2012, 51, 1977-1979. [CrossRef]

94. Morris, A.J.; Meyer, G.J.; Fujita, E. Molecular Approaches to the Photocatalytic Reduction of Carbon Dioxide for Solar Fuels. Acc. Chem. Res. 2009, 42, 1983-1994. [CrossRef]

95. Windle, C.D.; Perutz, R.N. Advances in Molecular Photocatalytic and Electrocatalytic $\mathrm{CO}_{2}$ reduction. Coord. Chem. Rev. 2012, 256, 2562-2570. [CrossRef]

96. Ziessel, R. Photochemical Reduction of Carbon Dioxide to Formate Catalyzed by 2, 2 t-Bipyridine- or 1, 10-Phenanthroline-Ruthenium(II) Complexes. J. Organomet. Chem. 1990, 382, 157-173.

97. Albert, J.; Wolfel, R. Selective Oxidation of Complex, Water-Insoluble Biomass to Formic Acid Using Additives as Reaction Accelerators. Energy Environ. Sci. 2012, 5, 7956-7962. [CrossRef]

98. Osaki, K.; Nakai, Y.; Watanabe, T. The Crystal Structures of Magnesium Formate Dihydrate and Manganous Formate Dihydrate. J. Phys. Soc. 1964, 19, 717-723. [CrossRef]

99. Sakaue, H.; Kinouchi, T.; Fujii, N.; Fujii, N.; Takata, T. Isomeric Replacement of a Single Aspartic Acid Induces a Marked Change in Protein Function: The Example of Ribonuclease, A. ACS Omega 2017, 2, 260-267. [CrossRef] [PubMed]

100. Buchanan, R.L.; Golden, M.H. Interactions between Ph and Malic Acid Concentration on the Inactivation of Listeria Monocytogenes. J. Food Saf. 1998, 18, 37-48. [CrossRef]

101. Søltoft-jensen, J.; Hansen, F. Emerging Technologies for Food Processing; Elsevier Ltd.: Philadelphia, PA, USA, 2005.

102. Van Havere, W.; Lenstra, A.T.H. Magnesium (+) -Malate Pentahydrate. Acta Crystallogr. 1980, B36, $2414-2416$. [CrossRef]

103. Gupta, M.P.; Van Alsenoy, C.; Lenstra, A.T.H. Magnesium Bis (Hydrogen Maleate) Hexahydrate, $\mathrm{Mg}\left[\mathrm{C}_{4} \mathrm{H}_{3} \mathrm{O}_{4}\right]_{2} \cdot 6 \mathrm{H}_{2} \mathrm{O}$. Acta Crystallogr. C-Cryst. Str. 1984, 40, 1526-1529. [CrossRef]

104. Johnson, E.C. Reference Module in Biomedical Sciences; Elsevier Inc.: Philadelphia, PA, USA, 2017.

105. Wang, J.; Wang, J.; Liu, J.; Wang, S.; Pei, J. Solubility of d -Aspartic Acid and 1-Aspartic Acid in Aqueous Salt Solutions from (293 to 343) K. J. Chem. Eng. Data 2010, 55, 1735-1738. [CrossRef]

106. Erreger, K.; Geballe, M.; Kristensen, A. Subunit-Specific Agonist Activity at NR2A-, NR2B-, NR2C-, and NR2D-Containing N-Methyl-d-Aspartate Glutamate Receptors. Mol. Pharmacol. 2007, 72, 907-920. [CrossRef] [PubMed]

107. Nyc, J.F.; Mitchell, H.K. Synthesis of Orotic Acid from Aspartic Acid. J. Am. Chem. Soc. 1947, 69, $1382-1384$. [CrossRef] [PubMed]

108. Schmidbaur, H.; Müller, G.; Rede, J.; Manninger, G.; Helbing, J. Ein Beitrag Zur Strukturaufklärung Des Pharmakologisch Wirksamen Magnesium-L-Aspartat-Komplexes. Angew. Chem. Int. Ed. Engl. 1986, 98, 1014-1016. [CrossRef]

109. Schmidbaur, H.; Bach, I.; Wilkinson, D.L.; Muller, G. The Crystal Structure of Racemic Magnesium Bis (Hydrogen Aspartate) Tetrahydrate Mg (L-AspH)(D-AspH)* 4H2O. Chem. Ber. 1989, 122, 1445-1447. [CrossRef]

110. Zheng, X.; Deng, L.; Baker, E.S. Distinguishing D- and L-Aspartic and Isoaspartic Acids in Amyloid $\beta$ Peptides with Ultrahigh Resolution Ion Mobility Spectrometry. Chem. Commun. 2017, 53, 7913-7916. [CrossRef]

111. Schmidbaur, H.; Bach, I.; Wilkinson, D.L.; Muller, G. Metal Ion Binding by Amino Acids. Preparation and Crystal Structures of Magnesium, Strontium, and Barium 1 -Glutamate Hydrates. Eur. J. Inorg. Chem. 1989, 122, 1433-1438. [CrossRef]

112. Pertzoff, V.A. Solubility of Glutamic Acid. J. Biol. Chem. 1933, 100, 97-104.

113. Plimmer, R.H. The Chemical Constitution of the Protein, 2nd ed.; Longmans, Green and Co.: London, UK, 1912.

114. Hassel, B.; Dingledine, R. Glutamate and Glutamate Receptors. In Basic Neurochemistry; Elsevier, Inc.: Philadelphia, PA, USA, 2012; pp. 342-366. 
115. Braitenberg, V.; Schuz, A. Cortex: Statistics and Geometry of Neuronal Connectivity, 2nd ed.; Springer: Berlin/Heidelberg, Germany, 2013.

116. Najafpour, G.D. Production of Citric Acid. In Biochemical Engineering and Biotechnology; Elsevier, B.V.: Amsterdam, The Netherlands, 2007; pp. 280-286.

117. Berg, J.M.; Tymoczko, J.L.; Stryer, L. Biochemistry, 5th ed.; W.H. Freeman: New York, NY, USA, 2002.

118. Oliveira, M.L.N.; Malagoni, R.A.; Franco, M.R. Solubility of Citric Acid in Water, Ethanol, n-Propanol and in Mixtures of Ethanol+water. Fluid Phase Equilib. 2013, 352, 110-113. [CrossRef]

119. Mansour, S.A.A. Thermal Decomposition of Magnesium Citrate 14-Hydrate. Thermochim. Acta 1994, 233, 231-242. [CrossRef]

120. Yang, K.; Chang, C.; Huang, J.; Lin, C.; Lee, G.; Wang, Y.; Chiang, M.Y. Synthesis, Characterization and Crystal Structures of Alkyl-, Alkynyl-, Alkoxo- and Halo-Magnesium Amides. J. Organomet. Chem. 2002, 648, 176-187. [CrossRef]

121. Manyak, A.R.; Murphy, C.B.; Martell, A.E. Metal Chelate Compounds of Glycylglycine and Glycylglycylglycine. Arch. Biochem. Biophys. 1955, 59, 373-382. [CrossRef]

(C) 2020 by the authors. Licensee MDPI, Basel, Switzerland. This article is an open access article distributed under the terms and conditions of the Creative Commons Attribution (CC BY) license (http://creativecommons.org/licenses/by/4.0/). 